\title{
Meeting in the Middle
}

\section{Introduction}

Over the last two decades Australia and New Zealand have become similar again, mirroring the closeness they shared when they first instituted social protections a century ago. Their current closeness, however, is based on very different regimes to those they began with 130 years ago. Differences remain between them despite the re-convergence. By the turn of the last century, New Zealand was beginning to re-think the major social protection diminutions that governments put in place in the 1990s. The subsequent policy direction has moved it closer to Australia's pattern. Employment relations have been partially re-collectivised in the Employment Relations Act of 2000. Social policy has moved toward integration with employment relations, evidenced mainly in 'workfare', New Zealand's own version of welfare activisation.

On the other side of the Tasman Sea, Australia began moving closer to New Zealand after the election of a Liberal/National Coalition government in 1996, bringing with it the demise of the Accord. The relationship between employment relations and social policy has since seen some de-coupling. The welfare activisation push has given way to a harsher 
workfare approach. In 2005, with the passing of the Workplace Relations Amendment (Work Choices) Act, employment relations were radically individualised, bringing Australia closer to New Zealand's predecessor legislative framework, the Employment Contracts Act. However, subsequent changes under the Fair Work Act of 2009 have brought Australia's legislation closer to the current New Zealand framework instead. In both countries, in addition to workfare, there is ongoing pressure from the progressive side of politics for government to attend to the adequacy of some social security payments.

Comparative accounts which cover the two regimes for the entire period since the mid-1990s are few, but those that exist tend to come from either the employment relations or the social policy perspective. Though there are authors who identify the general policy re-convergence between the two, identification of the factors that brought about the renewed similarities, and the continued differences, are patchy. Countering the increasing consensus that the re-convergence has been due mainly to material interests acting within the increasingly globalised economy, this chapter argues that the importance of traditional institutions have been most important.

The first section below discusses Australian developments. The second covers New Zealand. The third provides a comparative analysis.

\section{Australia}

Despite an increasingly polemical political landscape, social protection has not undergone radical change in Australia. To be sure, the conservative side of politics has made attempts in each of the two spheres of interest to move past the institutional impediments that have been in existence since Federation. Its success has been somewhat limited, though there have been some flexibilities to exploit. 


\section{Momentary Change Amid Continuity in Employment Relations}

The Accord process of the 1980s to the mid-1990s had provided the primary policy platform under Labor, but it was abandoned with the election of the Liberal-National Coalition government in 1996. The new prime minister, John Howard, was long committed to conservativism and was against genuine cooperation with the trade union movement. He saw unionism as antithetical to the public good. The first and most prominent opportunity taken by his government to target unions occurred in the lead-up to the 1998 waterfront dispute, which reflected an attempt to alter some of the central traditional characteristics of employment relations in Australia.

In 1998, members of the Maritime Union of Australia (MUA) were locked-out in four state capital city ports by their employer, Patrick Stevedores. Patrick was attempting to individualise employment contracts, casualise some full-time and permanent workers, and change work practices. The government not only sided with Patrick; it had actually instituted secret plans soon after forming government to actively assist Patrick to defeat the MUA (Davies 2018). During the dispute, the MUA took the matter to the Federal Court, and won, though in the end the company was able to achieve most of its desired objectives on workplace change (Dabscheck 2000; McConville 2000).

The government and Patrick were assisted in the waterfront dispute by the passing of the Workplace Relations Act in 1996. This replaced the Industrial Relations Act of 1993. It kept the Industrial Relations Commission but reduced the commission's role. Awards were to be stripped back to 20 'allowable matters', including minimum wage standards. The commission was made to sit alongside, and in some ways to compete with, a new third party called the 'Employment Advocate'. The role of the advocate was to process and approve new workplace deals called 'Australian Workplace Agreements'. These agreements, called AWAs for short, were subject to a 'no disadvantage' test for employees relative to the relevant award. Where there was a risk that they did or could disadvantage workers, the agreements could be referred to the 
commission. In contrast to awards, however, AWAs were between an employer and individual employees, though more than one employee could be covered on any one agreement. The commission retained its conciliation and arbitral functions, but only for 'protracted' disputes during the negotiation of agreements (Dabschceck 2001: 284-285).

The reduced role of the commission, the reduction of the number of items in awards, and the existence of Australian Workplace Agreements, all represented a partial individualisation of employment relations. That process was furthered significantly, however, by the introduction of the Workplace Relations Amendment (Work Choices) Act of 2005, or simply 'WorkChoices' as the government branded it. One of the main aims of WorkChoices was to expand federal government powers over employment relations. Yet, like its predecessor, the government needed to work around those powers rather than through them, relying on the 'corporations' and 'external affairs' clauses in the Constitution. Legal changes made in 1996, which were discussed in the previous chapter, used the corporation's power to allow employers to choose if they wished to be covered under the federal employment relations system. That choice was taken away by WorkChoices. Victoria had earlier signed on to transfer its employment relations powers to the Commonwealth, so all Victorian employers, regardless of sector, were treated as federal. In the other states, as long as the employer could be legally defined as a corporation, they would be subject to WorkChoices. The only exceptions there were organisations that were 'unincorporated' or were sole traders or partnerships (Stewart 2006: 28).

WorkChoices also sought eventually to completely contractualise agreement-making, and with some exceptions, the Industrial Relations Commission was to lose its compulsory arbitration powers. Most of these related to oversight of awards. The 'no disadvantage test' of enterprise agreements in comparison with the relevant award was abolished (Cowling and Mitchell 2007; Creighton 2011: 121). In theory, agreements could thus undercut minimum award standards, though exceptions existed for certain 'protected conditions' such as rest and meal breaks, annual leave loadings and incentive-based payments and bonuses. Minimum wages were to be set by a new 'Fair Pay Commission', which operated outside of AWAs and awards. WorkChoices also re-classified all 
agreements as either AWAs, which were individual, or 'collective agreements', which could be one of three sub-categories: 'union collective agreements', 'employee collective agreements', or 'greenfields agreements' (Stewart 2006). Awards would continue to operate for employees not covered by AWAs. Under AWAs, employment could be terminated by either party upon the expiry date of the agreement, with as little as 14 days' notice if that is specified in the agreement.

WorkChoices was an exceptional policy package for Australia, but the political environment within which it was introduced was somewhat exceptional. The Howard government, then in its final term of office, had taken control of both chambers of the parliament. Control of the Senate was unusual for governments of either persuasion. It was a rare and highly desirable gift for the party in power, and the Coalition took advantage of the legislative and policy opportunities this provided. Employment relations would prove electorally problematic, however, and the government was defeated in 2007, due in part to a successful campaign by the union movement against WorkChoices (Cooper and Ellem 2008: 542-546). It seemed that working people refused en masse to be convinced of the benefits of a more decentralised system that placed more onus on workers themselves to negotiate with their employers for improvements in wages and other working conditions.

The new Labor government understood the refusal, and indeed while still in Opposition, Labor was part of the campaign against WorkChoices. Kevin Rudd was the prime minister, though only until 2010, when Julia Gillard took over after a leadership coup. Rudd was again the leader after a second coup in the lead-up to the 2013 election (ABC 2013). Labor had won the 2007 election partly on the back of promises to be more deliberative and consultative in policy making (Commonwealth of Australia 2008). It also promised to 're-collectivise' employment relations by abolishing the making of new AWAs, and it replaced the Workplace Relations Act with a different regulatory programme (Creighton 2011). That programme took the form of the Fair Work Act of 2009, which still applies to the time of writing despite the continuous re-election of Coalition governments since 2013.

The first step taken by the Rudd government was to disallow the making of any new AWAs, though existing ones could serve their legal term 
up to a maximum of five years. The 'no disadvantage' test was revived. Both measures were taken through the enactment of the Workplace Relations Amendment (Transition to Forward with Fairness) Act of 2008. The Fair Work Act was subsequently introduced in 2009, with an emphasis on 'good faith' enterprise bargaining underpinned by 'National Employment Standards' (NES) as legally enforceable minima and with 'modern awards' and 'national minimum wage orders'. There were ten National Employment Standards, including those relating to working hours and working arrangements, various kinds of leave, notice of termination, and redundancy pay. The government's 'award modernisation' process, which was conducted by the Industrial Relations Commission, replaced the more than 1560 State and federal awards with just 122, and each award could cover 20 conditions. The Fair Work Act continued the practice of allowing non-award agreements, though the difference now was that these could in no way undercut award conditions. All workers would continue, however, to be covered by the National Employment Standards. Strike action could legally be taken and was deemed 'protected' under certain circumstances (Creighton 2011), but 'unprotected' action could leave employees vulnerable to common law action. This left unions in a vulnerable position.

In not specifying in detail the substantive differences between union and non-union collective agreements, the Fair Work Act cannot be said truly to live up to its promise to 're-collectivise' employment relations (Walpole 2015). This, in combination with the electoral damage caused by WorkChoices in 2010, explains why the Coalition has been largely unsuccessful in attempts to alter the Fair Work framework since its reelection in 2013. The main changes instituted have not been gamechanging in any sense (Wright 2018; Clibborn 2019), especially when viewed from the perspective of minimum labour standards. A partial exception, which indeed is beneficial rather than detrimental to social protection, is the Fair Work Amendment (Protecting Vulnerable Workers Act) of 2017, which extended employer liability provisions imposed upon franchisors and holding companies in cases of wage theft. This was largely in response to media coverage of the exploitation and underpayment of the typically casualised workers in retail chains such as 7-Eleven (Forsyth 2017). 
Employment relations policy as it stands could do a great deal more to ensure social protection for employees. However, at the time of writing, a newly elected Coalition government under the prime ministership of Scott Morrison appears instead to be seeking a return to a policy framework like that which briefly existed under WorkChoices (Olson 2019). Given the experience of recent years, this comes with the risk of once again alienating the government's voter base. It would also provide the union movement with renewed ammunition to fight for a new Labor election victory. It remains to be seen when such a victory will eventuate, and what it will mean for employment relations or social protection in general.

\section{Continued Coupling in Social Policy}

Since the mid-1990s there has been growing political pressure put on the welfare state, with increasing attempts by governments of both persuasions to use markets and the ideals of individualism in policy delivery (Western et al. 2007). While there have been differences between the Labor and Coalition sides, two central policy principles permeate and have become dominant across both sides. The first is that paid work is 'the best form of welfare'. This is the primary basis of the so-called workfirst approach to social policy (Marston and Dee 2015). The second is that those who receive monetary benefits from the government should be required to satisfy ever-stricter job-search requirements and to perform work and/or work-like activities in order to continue to receive benefits (Taylor et al. 2016; McGann et al. 2019).

As well as blending work and welfare, these principles aid the understanding of the role that employment relations plays in social policy. Just five years after the Labor government had lost power in 1996, the Accord dying with it, Frank Castles (2001) declared 'farewell to Australia's welfare state'. By 'welfare state' he meant the policy model underpinning the 'wage-earners' welfare state' as he had earlier theorised it (Castles 1985). Appropriately, Castles cites the drift towards enterprise bargaining as one means by which the wage-earners' welfare state has been dismantled. Issue is not taken here with that argument, but there are other means by 
which social policy has continued, and continues to the time of writing to liaise with employment relations policy. There have been two agendas in particular. The first is 'workfare', which is a stronger form of the activisation agenda that Australia was already pursuing in the late 1980s to the mid-1990s (Deeming and Johnston 2019; Ramia 2005). The second, allied with the first, has been 'welfare conditionality', which has been a feature of liberal welfare states in the past but is different and intensified in its contemporary forms (Dwyer 2019). Conditionality has come to be synonymous with three things: first, paternalistic attempts to compel welfare beneficiaries to contribute in market terms to the market society in which they live; second, attempts to alter the behaviour of beneficiaries, shifting it towards intensified, performative job-search; and third, punitive measures where beneficiaries do not conform to this kind of behaviour (Taylor et al. 2016). Conditionality is also manifested in the means used to deliver policy. Services to beneficiaries have increasingly involved contracting between government and organisations in the public, non-profit and private sectors, which theoretically compete against each other for the delivery rights. This has been particularly characteristic of Australia (Carney and Ramia 2002; Considine et al. 2015).

The Howard government accelerated and expanded this process considerably, radically stepping-up the limited contracting and contestability processes which were begun in employment services under the previous Labor government's Working Nation package. This involved abolishing the federal government's Commonwealth Employment Service and contracting-out its main functions, initially creating a managed market consisting of hundreds of organisations in the public, non-profit and for-profit sectors in what was then called the 'Job Network' (Ramia and Carney 2001). The 'network' approach introduced in the late 1990s created the most marketised system in the developed world for the provision of services to unemployed people. It infused services with increasing reliance on market reward incentives for providers in delivering services, and stepped-up activisation through the so-called mutual obligations agenda. In this way the conduct of service providers and benefit recipients was re-regulated. In addition, the government increased the discretionary powers of contracted organisations to penalise or 'sanction' unemployed people in cases where the latter did not fulfill their obligations. There was, and arguably still is, a widespread 
perception among policy makers that there was little need for government authorisation of non-government sanctioning. This has essentially privatised what had always previously been exclusively government prerogatives.

In the entire period of Howard's prime ministership from 1996 to 2007, the government also created the conditions for fostering more individual responsibility among those in retirement. Changes were introduced in health care to provide tax incentives to more members of community, especially the professional and middle classes, to take out private insurance (Ryan 2005). In family policy, Howard's social conservativism was manifested in measures to discourage workforce participation among mothers (Brennan 2007), while his government simultaneously subjected sole-parents to ever-greater 'activisation' through the extension of the mutual obligations agenda (Ramia et al. 2005). A strong form of paternalism was seen in the 'Norther Territory Intervention' into the communities and the lives of Indigenous Australians, including compulsory income management schemes (Marston et al. 2016; Mendes 2013). This kind of selectivity went beyond the traditional Australian principle of targeting in social security; the kind that has been discussed throughout the book. Whereas tradition involved a central emphasis on targeting, the discretion was kept solely within government, even under almost all of Labor's 'active society' measures as discussed in the previous chapter. Howard was instead placing increasing authority and trust in for-profit and non-profit service providers, allowing them more freedom to govern the lives of their job-seeking subjects. Accordingly, those in receipt of monetary benefits and services were increasingly beholden, as individuals, to both the government and organisations delivering human services in market settings.

The 2007 election, however, was dominated in terms of social protection by WorkChoices as the central plank of the employment relations agenda. Howard lost and Labor won. The new prime minister, Kevin Rudd, and Julia Gillard after him, became focused on the policy language of 'social inclusion', which in principle subsumed both social policy and employment relations. Howard had never used that term, let alone being committed to it, but Labor relied greatly upon it from its early days after winning office. The Labor approach revolved mostly around education 
and skills-enhancement, and despite the predominance of the language of 'inclusion', as Marston and Dee (2015) argue, it was a 'work-first' agenda. 'Being included' under Rudd and Gillard essentially meant 'being employed'. This principle shared great affinity with the previous government's emphasis on mutual obligations and workfare. Labor did not believe in addressing poverty, inequality and other social ills by means of policies that directly addressed them. Instead they created a Social Inclusion Board and invested in an associated, dedicated ministerial portfolio on social inclusion, initially given to Gillard as deputy prime minister.

Like the Coalition before it, Labor was 'market-reliant' (Johnson 2011) and it sought in general to continue the practice of making individuals responsible for their own welfare. The policy of compulsory income management for indigenous communities was rolled over from the Howard era and indeed trials in other communities were initiated as a means to address 'welfare dependency'. Tax rebates for private health insurance were kept. The Howard government's policy of keeping a major disparity between pensions and unemployment benefit payment, called Newstart, remained (Marston and Dee 2015). Indeed the Newstart rate has not increased in real terms to the time of writing, for a period of 25 years (Hilkermeijer et al. 2019). Under Labor the unemployed continued to be provided services in an employment network setting, though the number of organisations providing services decreased and the Job Network underwent a name change to Job Services Australia. The contracting regime was re-designed to be more conducive to personalised services, mainly through an emphasis on 'public value'. Yet services continued to be market-based (Ramia and Carney 2010). In sum, what appeared linguistically, and on the surface, to be a more progressive, welfare-oriented government, was mainly driven by continuity with its predecessor.

Labor lost office in 2013, in part due to having lost the electorate's confidence in the face of rotating prime ministerships. The Coalition has remained in office until the time of writing, though it has also gained a reputation nationally and internationally for changing prime ministers (BBC 2019), with three leadership 'spills' within the Coalition partyroom in the last four years and two changes of prime minister outside of election processes. The electorate was more focused on policy and 
political issues outside of who leads the Coalition, because the 2019 election was won shortly after the current prime minister, Scott Morrison, emerged as leader following a leadership challenge just months before. Two of the Coalition prime ministers, Morrison and Tony Abbot, have long-earned reputations as anti-welfare social conservatives. Malcolm Turnbull, the leader in between them, was more of an individualist, an economic conservative but a social progressive. He had many supporters in society because of this complex mix, but his policy record reflects that he served equally the Coalition's increasingly conservative values while in office (Taylor 2016).

Taking the three Coalition governments that have been in office since Labor was defeated in 2013, the common thread in social policy has been intensified anti-welfare political rhetoric. Though its ministers and other parliamentary members have never been totally united in social conservatism, key examples of the government effectively siding with conservative forces in society include its stances taken on 'religious freedom', freedom of speech, same-sex marriage and the broader rights of LGBTIQ communities (Hilkermeijer et al. 2019). Recent governments of both the Labor and Coalition varieties have been marked by continuum rather than differences. One important piece of evidence for this lies in the virtually unchanging rate of public expenditure on welfare, not only since the mid-1990s, but indeed since the early 1980s (Whiteford 2018).

It has been a principle informing this book, however, that social policy needs to be understood in terms of its relationship with the broader institutions of social protection. This goes well beyond the reliance on government expenditure. Even then, as can be seen in this chapter so far, change has been moderate. The commitment to activisation under Labor in the Accord years led to mutual obligations and the Job Network under the Howard-led Coalition government. From 2007, Labor's commitment to social inclusion effectively represented a continuum with that. Since 2013 the Coalition has re-branded the Job Network as 'JobActive', after Labor had re-named it Job Services Australia. The common thread throughout has been the use of market-based contracting as the primary regulatory means to provide employment and employment-allied services. The emphasis on conditionality, however, has been continuously increased, and it has been steadily extended to new categories of 
beneficiary; especially those that governments want to force to demonstrate more 'active' job-search. As well as the unemployed, this applies especially to youth, sole-parents, and people with disabilities.

\section{New Zealand}

The electoral system of New Zealand is the most important determinant of change in social protection since the mid-1990s. Mixed Member Proportional (MMP) voting was first used in the 1996 election, having been introduced in 1994. This was important in reflecting voter concerns over the accountability of governments for the policies they are constitutionally able to pursue. MMP has also seen unprecedented pressure for power-sharing amongst political parties in government, with every government since 1996 having to form coalitions. This has been instrumental in affecting the speed and the substance of detrimental policy change in relation to social protection (McAndrew 2010: 90). As revealed here, the change path of New Zealand has been dominated by a partial recollectivisation of employment relations and a movement in social policy towards integration with the world of employment. Both trends have meant that New Zealand and Australia look more alike than at any previous stage.

\section{'Good Faith Bargaining' and a 'Re-collectivisation' of Employment Relations?}

In 1997 Jenny Shipley replaced Jim Bolger as prime minister after a successful leadership challenge, in the process becoming New Zealand's first woman to officially lead the country. The governing Nationals subsequently suffered a breakdown in the relationship with their New Zealand First coalition partner. They lost office in 1999 to the Labour Party, which was in a coalition that was initially with various other parties. In 2000 under new prime minister, Helen Clark, the Employment Relations Act was introduced. It replaced the Employment Contracts Act and ushered in a major change 
process, the main objective of which was officially to restore a nominal power balance in the employment relationship.

The new act, which remains in force to the time of writing, was designed 'to build productive employment relationships through the promotion of good faith in all aspects of the employment environment and of the employment relationship' (Section 3a). It also sought to 'promote the effective enforcement of employment standards', principally by giving enforcement powers to a new labour inspectorate and by strengthening and streamlining arrangements for grievance handling. Other aims included increasing trust and confidence between employers and workers. Finally (Section 3), it was an objective to encourage collective bargaining for workers who were members of unions, and to make provision for negotiation for workers who were not.

Labour inspection processes were enhanced primarily through the introduction of a Mediation Service within the Department of Labour, whose representatives travelled to individual workplaces to help solve disputes at that level. Workers or employers could initiate mediation. At higher administrative levels, an Employment Relations Authority was set up as a means to solve disputes not solved by the mediator. The Employment Court, which had been set up under the Employment Contracts Act, continued to exist to decide on matters not resolved by the authority (Chelliah and Mukhi 2004: 11-12; McAndrew 2010).

It can be seen from the wording of the Employment Relations Act that the Clark government wanted to directly address the problems created by the Employment Contracts Act. However, the record of the act in this regard is mixed. In a rigorous assessment, Lafferty and Dorsett (2018) find that in the transition between the two acts, workplace outcomes and cultures were transformed. Further, they argue (p. 68) that the newer act 'rendered any resurrection of the 1990s decentralisation and deregulation of employment relations less politically plausible.' They also contend that minimum labour standards were improved within an environment that admittedly was and remains to this day predominantly decentralised. Their evidence is convincing, being based on multiple data sources. These include: surveys of collective agreements made under each of the two acts; surveys of non-wage clauses in industrial awards existing up to the introduction of the Employment Contracts Act; analysis of specific 
clauses on consultation in 82 collective agreements which covered highly unionised organisations employing more than 500 workers each; annual surveys of trade union membership; and face-to-face interviews with union officials who were active between 1991 and 2008, the latter being the final year of the Clark Labour government before its defeat at the hands of the Nationals.

As Lafferty and Dorsett (2018) highlight, the Employment Relations Act managed to address some of the extreme variations in conditions faced by workers. There was also evidence of a more good-faith approach to employment relations through workplace consultation and bargaining. There were increases in membership for some unions, though the public sector shows far more success than the private sector in that realm (Rasmussen 2010). Finally, increases to the minimum wage were more generous under the Employment Relations Act, which serves as a protection particularly relevant to non-unionised workers.

It is important, however, to re-emphasise that the gains from the new act were, and remain, partial. Decentralisation under the Employment Contracts Act was 'not total', mainly because the Employment Court was created by that act as a watchdog, and because the minimum wage concept was retained. Bargaining at the workplace level remained under the Employment Relations Act, as did the possibilities for individualised arrangements in workplaces that are decidedly anti-union (Burton 2010). Some also point out that the benefits of unionism under the Employment Relations Act can often easily flow to non-unionised workers through what is called 'passing on' (Kelly 2010). Finally, other benefits stemming from the current act do not take New Zealand back to the environment under any era existing before the Employment Contracts Act. The environment created in 1991 clearly had, and continues to have, its decentralist legacy.

To be sure, after several previous rounds of relatively small amendments to the act (Foster and Rasmussen 2017: 102), the Jacinda Ardernled Labour government, elected to power in 2017 and in power at the time of writing, has introduced a series of further changes (Employment New Zealand 2019). These include: improvements in provisions for rest and meal breaks; some enhancements in protection against worker dismissal; restrictions on the kinds of businesses that can hire workers on 
the basis of a 'trial period'; improved protections for workers in highly casualised industries; enhanced union entry rights into workplaces; and stepped-up protections against discrimination on the basis of union membership. Yet the fact that the amendments do not represent a change in the spirit of the act or the policy stance behind it, partly explains why the previous National-led governments of 2008 to 2017 did not opt to substantively repeal Labour's policy approach.

The work of political conservatives and free-marketeers, at least to some extent, had been done under the Employment Contracts Act. Its legacy lives on, and as will be seen in the comparative section of this chapter, it does so in relation to how connected employment relations can be to social policy.

\section{Coupling for the First Time? The New Zealand Social Policy Path}

Movements in social policy in New Zealand since the 1990s have been closely reflective of the traditions of the two major parties. National has moved it to the right of politics and Labour has moved it a little to the left. In this way it stands in contrast with employment relations, where both parties have kept the same overall framework, even if there have been party-based variations. Welfare activisation has been a part of policy in New Zealand, though more punitive forms have existed under the Nationals.

Activisation had its beginnings mainly in the mid-1990s while National was still in power under Jim Bolger's leadership. This was before the first MMP election. A report by the Prime Ministerial Taskforce on Employment, entitled Focus on Employment, recommended: case management for both young job-seekers and the long-term older unemployed; publicly funded childcare places for some unemployed; income support arrangements designed to encourage more active job-search; education and training initiatives; a Maori labour market strategy; and a separate Pacific Islanders strategy (New Zealand, Prime Ministerial Taskforce on Employment 1994). In addition, there was a scheme assisting sole-parent beneficiaries to (re-)enter paid work which was 
initially modelled on Australia's JET program from the 1980s (Nixon and McCulloch 1994; Rochford 1995). In an administrative change symbolising the closeness of employment and welfare, the Department of Social Welfare and the New Zealand Employment Service were merged, becoming Work and Income New Zealand (WINZ). Finally, a work-for-thedole scheme was introduced, whereby those receiving unemployment payments would 'work' for a so-called Community Wage, which served as the benefit and not an actual wage.

Australia had embraced activisation earlier than New Zealand, and New Zealand abandoned significant parts of it relatively quickly after implementation. The Community Wage - to give the example of the more stringent variety of workfare of the kind that governs the Australian system — was abandoned by the Clark Labour government in 2001. That government also made other welfare changes, some before that and some after, which added limited generosity back to the system. This included enhancements in assistance to low-income families as part of the Working for Families package. The relation of the minimum wage to the pension level was restored. Community housing was made more affordable by relating it to proportions of family income, and a Family Tax Credit was introduced as an additional boost to family incomes. All benefits were guaranteed pegging with the rate of inflation. Interest on student loans while students were still studying was abolished, and expenditure on early childhood education was increased. An in-work payment was established, replacing a child tax credit. Some labour market groups were exempted from work requirements when in receipt of unemployment payments, and the ministries that encompassed work and incomes were merged into a new ministry called Social Development (McClelland and St John 2005). In short, employment was still largely coupled with welfare in the broader policy context of a 'third way' approach (Piercy et al. 2017). The institutional pattern was a more social protection-friendly one and the coupling was a little less close.

The National government under John Key's leadership, with Bill English over its final year, was in office from 2008 to 2017. It took a more actuarial-based, 'social investment' approach to social policy (Maidment and Beddoe 2016) and was more broadly concerned with the obligation of beneficiaries to either work or to engage in education or training. This applied also to an increasing number of categories of benefit recipients, 
including sole-parents and people with disabilities, and it included income management for young beneficiaries (Baker and Davis 2018: 541). This is a version of the 'work-first' philosophy to which the chapter previously alluded in the Australia section. Key himself referred in 2009 to giving social security beneficiaries 'a kick in the pants when they are not taking responsibility for themselves, their family, and other taxpayers' (Gray 2019). In short, in the transition from a Clark Labour to a Key National government, the third way gave way to a stronger form of welfare conditionality, calling on beneficiaries to demonstrate behavioural change in exchange for the money they receive. To Australian observers this is a familiar story, though scholars on New Zealand more often use the term 'workfare' to describe the phenemona of welfare conditionality and activisation.

Since coming to office in 2017, Jacinda Ardern as the current Labour Prime Minister has sought first to conduct extensive reviews of policy across a wide range of areas, including the formation of a Welfare Experts Advisory Group (2019). Second, she has sought to instigate change in a more progressive direction (Fletcher 2019). Recognising that the increasingly stringent workfare model of the Nationals for the most part did not yield positive social progress or employability outcomes, her government has been focused on 'wellbeing', including the introduction of wellbeing measures to the national budget. This is in addition to instigating a new Families Package, measures to address homelessness and the affordability of both private and public housing, and making the first year of a university degree free for new students. The relationship between employment relations and social policy has not taken an historically distinctive shape to the time of writing, but it is in general a model that is closer to that of Australia's.

\section{What Is the Latest? A Comparative-Historical Analysis for Our Time}

An important message of this book has been that, if and where they endure, most of a nation-state's institutions through long histories can remain important to the present time. Given that, some of the comparative analysis of this chapter is partly pre-determined; though only partly. It is 
important to consider how much of the contemporary comparison is covered in the literature covering the last 25 years.

Scholarship is necessarily partial and patchy in its coverage of Australian and New Zealand social protection. Researchers can only be expected to probe questions that they set out to address. There are key large- $\mathrm{N}$ analyses which feature the two countries in multi-country studies, notably on unemployment benefit conditionality (Knotz 2018), corporatism (Siaroff 1999), social assistance (Gough 2001), and liberalism and neo-liberalism in the 'liberal' welfare state context (Deeming 2017). These are valuable studies in their own right. They do not specifically seek a deep understanding of the relationship between employment relations and social policy. Small-N or direct comparative analyses are more helpful, though it must be conceded that they mainly cover one or the other of the two primary areas of interest: social policy (McClelland and St John 2005) or employment relations (Barry and Wailes 2004; Bray and Rasmussen 2018; O'Donnell et al. 2011). The small-N authors also only cover part of the period to the present time, though an exception is Bray and Rasmussen's (2018) update on their analysis of 'accord and discord'. That perspective on the comparison has been discussed extensively in previous chapters. Finally, there are analyses which engage with Castles' (1985) original wage-earners' welfare state framework, or its more recent iterations (Castles 1994, 1996). These include my own writings (Ramia and Wailes 2006; Ramia 2005) and work by others (Deeming 2013; Wilson 2017; Wilson et al. 2013).

Despite the existence of this body of work, it has been demonstrated in this book that there is a need to analyse recent developments in light of a comprehensive comparative and historical narrative in the long haul. Using this narrative here, two questions need to be addressed. The first is, why did policy in Australia shift to the 'right', and in doing so move closer to the New Zealand regime? The second is, why did New Zealand shift to the 'left', and in doing so move closer to the Australian regime? Alternatively stated in one question, why did the two re-converge after having been very different in the previous period, from the early 1980 s to the mid-1990s?

As witnessed in the first section of this chapter, there are two main manifestations of Australia's move to the right. The first was the 
introduction of WorkChoices in 2005, which was a temporary move as that legislative programme was replaced by the Fair Work framework of the Rudd Labor government. Yet Fair Work did not take Australia back to the regulatory framework that existed before or during the Accord. Australia's employment relations system has remained relatively decentralised (Walpole 2015; Olson 2019). In that sense WorkChoices has left a legacy. The chapter has also shown that social policy has continued to be dominated by the policy legacies of the Howard government. This is despite the Rudd-Gillard Labor government having shifted the predominant policy language from 'mutual obligation' to 'social inclusion' (Marston and Dee 2015). As shown convincingly in the literature (Hilkermeijer et al. 2019; Taylor et al. 2016; McGann et al. 2019; Whiteford 2018), the Coalition governments since 2013 have variously continued and in some arenas toughened the social policy path toward individualisation.

On the other hand, New Zealand's move leftward and away from the radical starting point of 1996 is seen in two main developments. One development was the abandonment of the Employment Contracts Act and its replacement by the Employment Relations Act. The latter was introduced by the Clark Labour government but has been kept since then by both National and Labour governments alike. The other development was the adoption of a workfare agenda, which shared a basic similarity with Australia's version, precisely in terms of integrating employment and welfare. The second development is easier to explain than the first. Given that workfare in New Zealand was established while maintaining the government monopoly over the delivery of employment services, New Zealand policy has been closer to a 'third-way' approach in straddling the traditional Labour and National positions. It was less individualising while also embracing the mutuality of obligation (Piercy et al. 2017). The first phenomenon, being the introduction of the Employment Relations Act, has a more complex explanation, which is discussed below.

In explaining the similarities and differences, it is important to start with Australia, and specifically the Howard government's introduction of WorkChoices. Howard was able to capture both Houses of Parliament in the later years of his government. The fact that he did greatly assisted the passage of the legislation, but it also prompted the anti-WorkChoices 
political campaign by the trade union movement as well as the election campaign of the Labor Opposition. Both of these dimensions led to the defeat of the Coalition in 2007. Hence, in addition to the second parliamentary chamber, the relationship between the two arms of the labour movement were vital to moderating the employment relations agenda.

Explaining Australia's social policy trajectory is not as simple. The Rudd-Gillard Labor government largely maintained Howard's workfare agenda despite the adoption of different policy language, and despite changes in employment services which led to the re-naming and restructuring of the employment services network (Ramia and Carney 2010). The relatively harsh workfare agenda has been retained throughout (McGann et al. 2019). Once it had been brought in under Howard, subsequent governments have found it to be electorally expedient to continue.

On the New Zealand side of the Tasman, again institutional and political considerations are most important. As pointed out in the previous section, the last government to have won office on the first-past-the-post electoral system was National, led by Bolger. That government was the most radical-right on social protection in terms of both social policy and employment relations. Policy making since that election, in 1996, is arguably most influenced by the new voting regime in combination with a sense of fatigue with hard-right policy (McAndrew 2010). It is no accident that no government since 1996 has been able to win and maintain office while not in a coalition. That requires policy compromise and works against extremes in policy.

\section{Conclusion}

In addition to the comparative picture painted here, perhaps the most important indicator that the New Zealand and Australian policy patterns have met in the middle is that both countries have maintained a thirdparty industrial arbitration function. It will be recalled that historically the fate and the status of arbitration is the single most influential factor on the path taken in social protection. The function is not identical in the two countries, and in New Zealand's case it was re-established in different 
circumstances, and perhaps ironically as part of the Employment Contracts Act. Yet there is a re-convergence in more recent times. As well as the factors already identified, this is seen in the state of the union movement, which is lower in density and power than it historically was in both countries. Minimum labour standards once again also look similar, and both countries continue to embrace workfare, even if Australia is a three-sector model based on contestability and New Zealand maintains a government monopoly in employment services provision.

The period to the current time is less action-packed than the previous period, mainly because it is a period characterised mainly by similarity. It is also less exciting in the sense that the groundwork for restructuring had been laid earlier, in the 1980s and 1990s. Of course, this is only talking in terms of institutional change, and not the social effects of that change. The analysis here has been mainly about the processes of change, and not the measurement of institutional or policy impact. That would be more suitable for economic studies.

\section{References}

ABC. (2013). As It Happened: Kevin Rudd Faces Question Time After Taking Over as Prime Minister. $A B C$ News, at: https://www.abc.net.au/news/specials/rudd-returns/2013-06-27/live-blog-rudd-sworn-in-as-primeminister $/ 4784070$

Barry, M., \& Wailes, N. (2004). Contrasting Systems? 100 Years of Arbitration in Australia and New Zealand. Journal of Industrial Relations, 46(4), 430-447. BBC. (2019, May 18). Scott Morrison: Australia's Conservative Pragmatist. BBC News, Online, at: https://www.bbc.com/news/world-australia-45292331

Bray, M., \& Rasmussen, E. (2018). Developments in Comparative Employment Relations in Australia and New Zealand: Reflections on 'Accord and Discord'. Labour and Industry, 28(1), 31-47.

Brennan, D. (2007). Babies, Budgets and Birthrates: Work/Family Policy in Australia 1996-2006. Social Politics, 14(1), 31-57.

Burton, B. (2010). Employment Relations 2000-2008. In E. Rasmussen (Ed.), Employment Relationships: Workers, Unions and Employers in New Zealand (pp. 94-115). Auckland: Auckland University Press.

Carney, T., \& Ramia, G. (2002). From Rights to Management: Contract, New Public Management and Employment Services. The Hague: Kluwer. 
Castles, F. G. (1985). The Working Class and Welfare: Reflections on the Political Development of the Welfare State in Australia and New Zealand, 1890-1980. Wellington/Sydney: Allen and Unwin.

Castles, F. G. (1994). The Wage Earners' Welfare State Revisited: Refurbishing the Established Model of Australian Social Protection, 1983-93. Australian Journal of Social Issues, 29(2), 120-145.

Castles, F. G. (1996). Needs-based Strategies of Social Protection in Australia and New Zealand. In G. Esping-Andersen (Ed.), Welfare States in Transition: National Adaptations in Global Economies (pp. 88-115). London: SAGE Publications.

Castles, F. G. (2001). A Farewell to Australia's Welfare State. International Journal of Health Services, 31(3), 537-544.

Chelliah, J., \& Mukhi, S. K. (2004). A Chronological Analysis of the Evolution of Industrial Relations in New Zealand. Proceedings of the 12th Annual Conference of the International Employment Relations Association: 'Regionalism and Globalisation - The Challenge for Employment Relations'. Yeppoon, Qld: International Employment Relations Association.

Clibborn, S. (2019). Australian Industrial Relations in 2018: Inequality, Policy Stagnation and a Brewing Storm. Journal of Industrial Relations, 61(3), 318-325.

Commonwealth of Australia. (2008). Australia 2020: Final Report. Canberra: Commonwealth of Australia.

Considine, M., Lewis, J., O’Sullivan, S., \& Sol, E. (2015). Getting Welfare to Work: Street-Level Governance in Australia, the UK, and the Netherlands. Oxford: Oxford University of Press.

Cooper, R., \& Ellem, B. (2008). The Neoliberal State, Trade Unions and Collective Bargaining in Australia. British Journal of Industrial Relations, 46(3), 532-554.

Cowling, S., \& Mitchell, W. (2007). Taking the Low Road: Minimum Wage Determination under Work Choices. Journal of Industrial Relations, 49(5), 741-756.

Creighton, B. (2011). A Retreat from Individualism? The Fair Work Act 2009 and the Re-Collectivisation of Australian Labour Law. Industrial Law Journal, 40(2), 116-145.

Dabschceck, B. (2001). The Slow and Agonising Death of the Australian Experiment with Conciliation and Arbitration. Journal of Industrial Relations, 43(3), 277-293.

Dabscheck, B. (2000). The Australian Waterfront Dispute and Theories of the State. Journal of Industrial Relations, 42(4), 497-516.

Davies, A. (2018, December 31). How the Howard Government Set Up its Bruising 1998 Waterfront Union Showdown. The Guardian, at: https:/www. 
theguardian.com/australia-news/2019/jan/01/how-the-howardgovernment-set-up-its-bruising-1998-waterfront-union-showdown

Davis, A. (2018). How the Howard Government Set Up Its Bruising 1998 Waterfront Union Showdown. The Guardian. https://www.theguardian. com/australia-news/2019/jan/01/how-the-howard-government-set-up-itsbruising-1998-waterfront-union-showdown

Deeming, C. (2013). The Working Class and Welfare: Francis G. Castles on the Political Development of the Welfare State in Australia and New Zealand Thirty Years on. Social Policy and Administration, 47(6), 668-691.

Deeming, C. (2017). The Lost and the New 'Liberal World' of Welfare Capitalism: A Critical Assessment of Gøsta Esping-Andersen's The Three Worlds of Welfare Capitalism a Quarter Century Later. Social Policy and Society, 16(3), 405-422.

Deeming, C., \& Johnston, R. (2019). From 'Welfare' to 'Workfare', and Then Back Again? Social Insecurity and the Changing Role of the State. In J. Evans, S. Ruane, \& H. Southall (Eds.), Data in Society: Challenging Statistics in an Age of Globalisation. Bristol: Policy Press.

Dwyer, P. (Ed.). (2019). Dealing with Welfare Conditionality: Implementation and Effects. Bristol: Policy Press.

Employment New Zealand. (2019). Employment Relations Amendment Act 2018. Employment New Zealand, at: https://www.employment.govt.nz/about/ employment-law/employment-relations-amendment-act-2018/

Fletcher, M. (2019). Towards Wellbeing? Developments in Social Legislation and Policy in New Zealand. Social Law Reports, No. 2/2019. Munich: Max Planck Institute for Social Law and Social Policy.

Forsyth, A. (2017). Industrial Legislation in Australia in 2016. Journal of Industrial Relations, 59(3), 323-339.

Foster, B., \& Rasmussen, E. (2017). The Major Parties: National's and Labour's Employment Relations Policies. New Zealand Journal of Employment Relations, 42(2), 95-109.

Gough, I. (2001). Social Assistance Regimes: A Cluster Analysis. Journal of European Social Policy, 11(2), 165-170.

Gray, C. (2019). The Implementation and Impact of National's Welfare Conditionality in an International Context. New Zealand Sociology, 34(2), 71-92.

Hilkermeijer, A., Maguire, A., Gelber, K, \& Whiteford, P. (2019). The Coalition's Record on Social Policy: Big on Promises, Short on Follow-Through. The Conversation, Online, at: https://theconversation.com/the-coalitions-recordon-social-policy-big-on-promises-short-on-follow-through-114611

Johnson, C. (2011). Gillard, Rudd and Labor Tradition. Australian Journal of Politics and History, 57(4), 562-579. 
Kelly. (2010). Challenges and Opportunities in New Zealand Employment Relations: A CTU Perspective. In E. Rasmussen (Ed.), Employment Relationships: Workers, Unions and Employers in New Zealand (pp. 133-148). Auckland: Auckland University Press.

Knotz, C. M. (2018). A Rising Workfare State? Unemployment Benefit Conditionality in 21 OECD Countries, 1980-2012. Journal of International and Comparative Social Policy, 34(2), 91-108.

Lafferty and Dorsett. (2018). Surviving on the Brink: New Zealand Workers, Unions and Employment Relations, 1991-2008. Labour History, (115), 76-85.

Maidment, J., \& Beddoe, L. (2016). Social Policy, Social Work and Social Change. In J. Maidment, \& L. Beddoe (Eds.), Social Policy for Social Work and Human Services in Aotearoa New Zealand (pp. 21-33). Christchurch: University of Canterbury Press.

Marston, G., \& Dee, M. (2015). The Social Inclusion Policy Agenda in Australia: A Case of Old Wine, New Bottles? Australian Journal of Social Issues, 50(2), 119-138.

Marston, G., Cowling, S., \& Bielefeld, S. (2016). Tensions and Contradictions in Australian Social Policy Reform: Compulsory Income Management and the National Disability Insurance Scheme. Australian Journal of Social Issues, 51(4), 399-417.

McAndrew, I. (2010). The Employment Institutions. In E. Rasmussen (Ed.), Employment Relationships: Workers, Unions and Employers in New Zealand (2nd ed.), (pp. 74-93). Auckland: Auckland University Press.

McClelland, A., \& St John, S. (2005). Social Policy Responses to Globalisation in Australia and New Zealand, 1980-2005. Australian Journal of Political Science, 41(2), 177-191.

McConville, C. (2000). The Australian Waterfront Dispute 1998. Politics and Society, 28(3), 393-412.

McGann, M., Nguyen, P., \& Considine, M. (2019). Welfare Conditionality and Blaming the Unemployed. Administration \& Society, Online Early, at: https://journals.sagepub.com/doi/pdf/10.1177/0095399719839362

Mendes, P. (2013). Compulsory Income Management: A Critical Examination of the Emergence of Conditional Welfare in Australia. Australian Social Work, 66(4), 495-510.

New Zealand, Prime Ministerial Taskforce on Employment. (1994). Employment: The Issues, Prime Ministerial Taskforce on Employment. Wellington: New Zealand Government.

Nixon, A., \& McCulloch, F. (1994, July). Facilitation of Sole Parents into Paid Work. Social Policy Journal of New Zealand, (2). 
O’Donnell, M., O’Brien, J., \& Junor, A. (2011). New Public Management and Employment Relations in the Public Services of Australia and New Zealand. International Journal of Human Resource Management, 22(11), 2367-2383.

Olson, W. (2019). Industrial Relations Overhaul Could Hurt Unions and Workers. Independent Australia. https://independentaustralia.net/business/ business-display/industrial-relations-overhaul-could-hurt-unions-andworkers, 13035

Piercy, G. L., Mackness, K., Rarere, M., \& Madley, B. (2017). Investigating Commentary on the Fifth Labour-led Government's Third Way Approach. New Zealand Sociology, 32(1), 51-75.

Ramia, G. (2005). Industrial Relations in the Context of Workfare: Comparing Australia and New Zealand. New Zealand Journal of Employment Relations, (3093), C1-C14.

Ramia, G., \& Carney, T. (2001). Contractualism, Managerialism and Welfare: The Australian Experiment with a Marketised Employment Services Network. Policy \& Politics, 29(1), 59-80.

Ramia, G., \& Carney, T. (2010). The Rudd Government's Employment Services Agenda: Is it Post-NPM and Why is that Important? Australian Journal of Public Administration, 69(3), 263-273.

Ramia, G., \& Wailes, N. (2006). Putting Wage-Earners into Wage Earners' Welfare States: The Relationship Between Social Policy and Industrial Relations in Australia and New Zealand. Australian Journal of Social Issues, 4(1), 49-68.

Ramia, G., Chapman, A., \& Michelotti, M. (2005). How Well do Industrial Relations and Social Policy Interact? Labour Law and Social Security Law in the Social Protection of Sole Parents. International Journal of Comparative Labour Law and Industrial Relations, 21(2), 249-279.

Rasmussen, E. (2010). Introduction. In E. Rasmussen (Ed.), Employment Relationships: Workers, Unions and Employers in New Zealand (pp. 1-8). Auckland: Auckland University Press.

Rochford, M. (1995). Evaluating the Compass Pilot Programme. Social Policy Journal of New Zealand, (5), 163-172.

Ryan, N. (2005). A Decade of Social Policy Under John Howard: Social Policy in Australia. Policy \& Politics, 33(3), 451-460.

Siaroff, A. (1999). Corporatism in 24 Industrial Democracies: Meaning and Measurement. European Journal of Political Research, 36(2), 175-205.

Stewart, A. (2006). Work Choices in Overview: Big Bang or Slow Burn? Economic and Labour Relations Review, 16(2), 25-60. 
Taylor, L. (2016, May 16). The Long Game: Will Malcolm Turnbull's Gamble Pay Off? The Guardian, Australian Edition, at: https://www.theguardian. com/australia-news/2016/may/17/election-2016-malcolm-turnbull-liberalparty-coalition-profile

Taylor, D. R., Gray, M., \& Stanton, D. (2016). New Conditionality in Australian Social Security Policy. Australian Journal of Social Policy, 51(1), 3-26.

Walpole, K. (2015). The Fair Work Act: Encouraging Collective AgreementMaking but Leaving Collective Bargaining to Choice. Labour and Industry, 25(3), 205-218.

Western, M., Baxter, J., Pakulski, J., Tranter, B., Western, J., van Egmond, M., Chsters, J., Hosking, A., OFlaherty, M., \& van Gellecum, Y. (2007). Neoliberalism, Inequality and Politics: The Changing Face of Australia. Australian Journal of Social Issues, 42(3), 401-418.

Whiteford, P. (2018, November 30). Why Social Policy Counts. Inside Story, at: https://insidestory.org.au/why-social-policy-counts/

Wilson, S. (2017). The Politics of 'Minimum Wage' Welfare States: The Changing Significance of the Minimum Wage in the Liberal Welfare Regime. Social Policy \& Administration, 51(2), 244-264.

Wilson, S., Spies-Butcher, B., Stebbing, A., \& St John, S. (2013). Wage-Earners' Welfare After Economic Reform: Refurbishing, Retrenching or Hollowing Out Social Protection in Australia and New Zealand? Social Policy and Administration, 47(6), 623-646.

Wright, C. F. (2018). Australian Industrial Relations in 2017. Journal of Industrial Relations, 60(3), 287-297.

Open Access This chapter is licensed under the terms of the Creative Commons Attribution 4.0 International License (http://creativecommons.org/licenses/ by/4.0/), which permits use, sharing, adaptation, distribution and reproduction in any medium or format, as long as you give appropriate credit to the original author(s) and the source, provide a link to the Creative Commons licence and indicate if changes were made.

The images or other third party material in this chapter are included in the chapter's Creative Commons licence, unless indicated otherwise in a credit line to the material. If material is not included in the chapter's Creative Commons licence and your intended use is not permitted by statutory regulation or exceeds the permitted use, you will need to obtain permission directly from the copyright holder. 